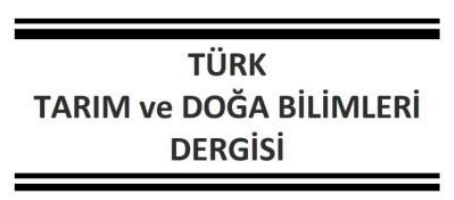

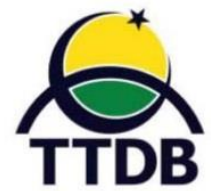

www.dergipark.gov.tr/turkjans

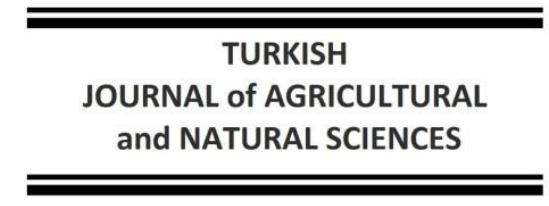

and NATURAL SCIENCES

\title{
Araştırma Makalesi \\ Molecular Phylogeny of Some Geophytes Taxa from Turkey; Systematic Approaches
}

\author{
Alpaslan KOÇAK ${ }^{1 *}$, Gülden KOÇAK ${ }^{1}$, ilyas DENiZ ${ }^{2}$ \\ ${ }^{1}$ Department of Molecular Biology and Genetics, Art and Science Faculty, Bingol \\ ${ }^{2}$ ÇDepartment of Biology, Art and Science Faculty, Bingol \\ *Corresponding Author: akocak@bingol.edu.tr
}

Received: 13.07.2021 Received in Revised: 03.12.2021 Accepted: 13.01.2022

\begin{abstract}
To determine the evolutionary relationships among some members of geophytes collected from their natural habitat in Kulp-Diyarbakır we carried out molecular phylogenetic analysis of one nuclear DNA (nrDNA) region (internal transcribed spacer, ITS) and one chloroplast DNA (cPDNA) region (intergenic spacer region of trnL-F). Despite phylogenetic analysis using maximum likelihood done by two different DNA source show some differences. It was identified that monocotyl petaloid taxa differ from dicotyledone geophyte ones. Also both phylogenetic trees reveal that Serapias L., Anacamptis Rich., Cephalanthera Rich., Himanthoglossum Spreng. and Dactylorhiza Necker ex Nevski are nested in Orchis L. Therefore the infraspecific relationships of these genera should be re-evaluated according to our molecular phylogenetic study results. Dicotyl geophyts show molecular phylogeny in accordance with the classical systematic order in Flora of Turkey and reveal the accuracy of interspecific and infraspecific distinctions of these taxa.
\end{abstract}

Key words: Geophytes, ITS, trnL-F, Molecular phylogeny

\section{Türkiye'ye Ait Bazı Geofit Taksonlarının Moleküler Filogenisi, Sistematik Yaklaşımlar}

\section{Öz}

Bu çalışmada Kulp-Diyarbakır bölgesindeki doğal habitatlarından toplanan geofitlerin bazı üyeleri arasındaki evrimsel ilişkileri belirlemek için nükleer DNA (nrDNA) bölgesi (internal transkribed spacer, ITS) ve kloroplast DNA(cpDNA) bölgesinin (intergenic spacer, trnL-F) moleküler filogenetik analizi gerçekleştirdik. íki farklı DNA kaynağı kullanılarak yapılan maximum likelihood (en büyük olabilirlik kestirimi) yöntemi kullanılarak çizilen filogenetik ağaçlar bazı farklılıklar göstermesine rağmen monokotil petaloid taksonların dikotiledon geofit taksonlarından ayrıldığı görülmüştür. Ayrıca her iki moleküler marker kullanılarak gerçekleştirilen filogenetik analizlerde Serapias L., Anacamptis Rich., Cephalanthera Rich., Hymanthoglossum Spreng. ve Dactylorhiza Necker ex Nevski cinslerinin Orchis L. içerisine dahil olduğu görülmüştür. Bu nedenle, bu cinse ait alt türlerin akrabalık ilişkileri bizim sonuçlarımıza göre yeniden değerlendirilmelidir. Dikotil geofitler, Flora of Turkey'deki klasik sistematik düzene göre moleküler filogeni göstermekte ve bu taksonların tür içi ve türler arası ayrımlarının doğruluğunu ortaya koymaktadır.

Anahtar kelimeler: Geofit, ITS, trnL-F, moleküler filogeni.

\section{Introduction}

The greatest diversity of bulbs, including petaloid monocotyledons with corms, rhizomes and tubers, can be found in the Flora of Turkey. A classification of plants, proposed by the Danish botanist C. Raunkiaer, based on the position of perennating buds in relation to the soil surface. These are chamaephyte; epiphyte; geophyte; hemicryptophyte; phanerophyte; therophyte. Raunkiaer (1934) has classified plants according to the place where the growth point is located during the less favorable seasons, provided the plant maintains the capability to survive these difficult 
condition. 'Geophyte' is a Latin word which means 'ground plants or hidden plants' and it is formed by the combination of the words "geo" meaning 'place' and 'phyta' meaning plant. The stems of these plants are metamorphosed in the form of bulb, tuber, corm or rhizome and are located below the soil level (Anonymous, 2020). The geophytes, plants with underground perennating organs like bulbs, corms, tubers or rhizomes lose their aerial parts annually. Perennial belowground elements allow plants to survive periods of severe climate conditions (Dafni et al., 1981; Parsons, 2000; Procheş et al., 2005; Procheş et al., 2006; Kamenetsky, 2013). According to Zencirkıran (2002), although the aboveground organs dry out after completing their development in the growing season, geophytes; are biannual or perennial plants that have organs that can survive under the ground. In geophytes, budding occurs under the ground, while other plants are at or above the ground level. Furthermore, it is known that species of geophytes in different lineages of angiosperms have increased their genome size, facilitating the production of larger cells in the underground perennating organs, which is advantageous for fast growth in seasonal habitats (Vesely et al., 2012).

Geophytes are often conspicuous components of vegetation after burning (Doussi and Thanos, 2002; Verboom et al., 2002; Tyler and Borchert, 2003; Koniak et al., 2009). This life form is more common in monocots, in families like Iridaceae, Orchidaceae, Hyacinthaceae, Amaryllidaceae and Anthericaceae and only occurs in very few dicot taxa (Meerow, 2013). Geophytes have an economic value due to their use in the pharmaceutical industry and remarkable flowers (Güner et al., 1991). Due to their aesthetic properties, fragrances and usability as cut flowers, they are the most preferred plants among ornamental plants (Çığ and Başdoğan, 2015). Geophytes create a strong visual impact due to contribute to the enrichment of landscape both aesthetically and functionally. With the help of their year round blooming feature, they avoid monotony in landscape designs. (Seyidoğlu et al., 2009). Geophytes are used in many areas such as. rock gardens, curbs, grass areas, building entrances, roadsides. In recent years, it has been given possibility of having the impressive design with the participation of Geophytes to planting works (Akdeniz and Zencirkıran, 2016).

Turkey is very rich in native plant diversity which in proportion to its area. The main reasons for this, being at the intersection of different phytogeographical region and different elevation and habitat diversity as well as climatic features. Within the studies about the natural flora in recent years, it is revealed that Turkey's flora consists of about 12500 plant taxa (Özhatay et al., 2003). Geophytes are an important part of this rich flora. According to Davis (1965-1985) geophytes are represented by nearly 600 plant taxa in Turkey and about $40 \%$ of them is endemic. This number is 800 according to Güner (2006) and 900 according to Kandemir and Yakupoğlu (2016).

The economic and evolutionary importance of these taxa warrant increased scientific attention. To date, most studies pertaining to geophyte evolution have focused on a handful of taxonomic groups (Patterson and Givnish, 2002; Perret et al., 2003; Wilson, 2006; Oberlander et al., 2009; Evans et al., 2014; Sosa et al., 2016) or geographic regions (Pate and Dixon, 1982; Rundel, 1996; Hoffmann et al., 1998; Parsons, 2000; Parsons and Hopper, 2003; CuéllarMartínez and Sosa, 2016; Sosa and Loera, 2017).

Because of minimal distinction of genetic, phenotypic and morphological characteristics, interspecific gene flow and incomplete classification of lineage sorting (Ebersberger et al., 2007) it is inconvenient to find out phylogenetic relationships among groups that have diverged recently and/or rapidly (Mallo and Posada, 2016; Fernández-Mazuecos, et al., 2017). Today, molecular phylogenetic approaches aim to investigate many new genomic regions and create their combinations for reflecting history accurately (i.e., the "species tree"; Ebersberger, et al., 2007).

The aim of this study is to provide first report on the phylogenetic relationship of geophytes grown naturally in Kulp-Diyarbakır. In this study, we used molecular data from entire nrDNA ITS region and we further included sequence information from the cpDNA intergenic spacer between the trnL (UAA) 3' exon and trnF (GAA) to provide a more comprehensive taxonomic and phylogenetic results and a more stable classification.

\section{Material and Methods}

Plant material: Plant material was obtained from silica-gel dried leaved of collected specimens in the wild. from natural habitats in KulpDiyarbakır, 2020. The plant materials were identified by Dr. A. Koçak according to Flora of Turkey and East Aegean Islands (Davis, P.H. 19651985). Voucher specimens were deposited at the Molecular Biology and Genetics Laboratory of Bingol University. Plant taxa used in this study; Orchis coriophora L., O. mascula (L.) L. subsp. pinetorum (Boiss \& Kotschy) G. Camus, $O$. punctulata Steven ex Lindley, O. Iaxiflora Lam., $O$. anatolica Boiss., O. simia Lam., O. papilionacea L. subsp. papilionacea, O. tridentata Scop, Allium 
scorodoprasum L. subsp. rotundum (L.) Stearn, $A$. pallens L. subsp. pallens, A. cardiostemon Fisch. \& C.A. Mey, A. wiedemannianum Regel, Eminium rauwolffii (Blume) Schott var. rauwolffii, Scilla siberica Haw. subsp. armena (Grossh.) Mordak, Ixiolirion tataricum (Pall.) Schult. \& Schult.f. var. tataricum, Gynandriris sisyrinchium (L.) Parl., Fritillaria imperialis L., F. minuta Boiss. \& Noë., Anacamptis pyramidalis (L.) Rich., Himantoglossum affine (Boiss.) Schltr., $H$. comperianum (Steven) P.Delforge, Ranunculus millefolius Sol., subsp. millefolius, R. kotchii Ledeb., R. asiaticus L., $R$. cuneatus Boiss., Muscari comosum (L.) Mill., Corydalis caucasica DC. subsp. caucasica, Anemone coronaria L., Gagea luteoides Stapf., G. villosa (M.Bieb.) Sweet var. villosa, G. commutata K.Koch. (Güner, 2018), Gladiolus italicus Mill., Bunium paucifolium DC., Tulipa armena Boiss var. armena, Ornithogalum umbellatum L., Serapias vomeracea (Burm.f.) Briq, Colchicum szovitsii Fsich. \& C.A. Mey. subsp. szovitsii, Dactylorhiza romana (Seb.) Soó subsp. romana, Iris reticulata M.Bieb. var. reticulata, I. persica L., Crocus biflorus Mill. subsp. tauri (Baw) B.Mathew, Cephalanthera longifolia (L.) Fritsch, Geranium libanoticum Schenk.

DNA extraction, amplification, and sequencing: Total genomic DNA was extracted by Plant DNA isolation kit supplied by MachereyNagel. Polymerase chain reaction (PCR) of the whole region of nrDNA ITS were performed using the ITS AB101 and ITS AB102 primers (Douzery et al., 1999). PCR amplifications were conducted according to the protocols described in Sonboli et al. (2010). Amplification of intergenic spacer between the trnL (UAA) 3' exon and trnF (GAA) (B49873 and A50272 primers) was performed according to the protocols of Taberlet et al. (1991). Sequencing reactions were performed using $A B I$ 3730 XL (Applied Biosystems).

Alignment and phylogenetic analyses: Phylogenetic analysis were undertaken using ITS1 and ITS2 and trnL-F data sets of samples and each included the sequences from the GenBank database of the National Center for Biotechnology Information (NCBI; http://www.ncbi.nlm.nih.gov/) were aligned using ClustalW (Thompson et al., 1994) software and subsequently checked visually (Table 1). Variable sites, number of parsimonyinformative sites, transition, transversion, genetic distance, nucleotide diversity, and divergence within species were computed as molecular diversity statistics for each dataset using Molecular Evolutionary Genetics Analysis software (MEGA 11.0; Tamura et al., 2021). Ultimately, phylogenetic trees were constructed by Maximum Likelihood Method with 1000 bootstrap replicates.

\section{Results and Discussion}

The aligned data set of entire ITS and trnLF included a total of 78 (41), and 60 (18) taxa and taxa number taken from GenBank is specified in parenthesis. ITS and trnL-F sequences length, GC\% content, conserved sites, parsinomy informative and variable sites statistics are showed in Table 2 .

In total 48 plant taxa among to geophytes were collected from their natural grown area in KulpDiyarbakır. Two different primer sites ITS5-ITS4 and A101-A102 were used in PCR reactions for multiplication of nrDNA ITS1, 5.8S and ITS2 regions all of them gave bands around $850-900 \mathrm{bp}$. Together with 37 taxa nrDNA ITS1, 5.8S and ITS2 regions DNA sequences 41 taxa sequences found from GenBank and evaluated for phylogenetic tree construction. Two sets of primers were used for polymerization of spacer between the trnL (UAA) $3^{\prime}$ exon and trnF (GAA) from chloroplast DNA (cpDNA). All of the samples were amplified with the primer set used for polymerization of intergenic spacer between the trnL (UAA) 3' exon and $\operatorname{trn} \mathrm{F}$ (GAA) cpDNA. All gave bands between 300-350 bp. 18 different sequences obtained from GenBank and were added during phylogenetic tree evaluation.

According to our nrDNA analysis results, it is clearly seen that monocotyl petaloid taxa differ from dicotyledonae geophyte ones (Figure 1). Also Orchidaceae family members were completely separated from dicotyledonae geophytes and other monocotyl petaloid families that studied. According to our chloroplast DNA analysis results, all taxa members of monocotyl petaloid came together and completely separated from dicotyl geophyt taxa (Figure 2). Both nrDNA and cpDNA results show that the description of Orchis, Serapias, Anacamptis, Cephalanthera, Hymanthoglossum and Dactylorhiza genera should be done very carefully. The infraspecific relationships of these genera should be reevaluated according to our molecular phylogenetic study results. Any phylogenetic problems are not observed in the description of other monocotyl petaloid genera. The studied dicotyl geophyts show molecular phylogeny in accordance with the classical systematic order in Flora of Turkey and reveal the accuracy of interspecific and infraspecific distinctions of these taxa. When compared at the family classification in Flora of Turkey, all genus were gathered together according to the ITS sequence analysis. Despite the enormity of the nuclear genome derived ITS sequences, Iridaceae and Liliaceae are not coherent to this classification according to the trnLF data. 
Previous studies indicate that molecular data strongly verify the monophyly of Liliaceae (Thomas et al., 2002). Fay et al., (2006) separated the Liliaceae some clades namely, clade A, B, C, D, and $\mathrm{E}$ depends on the results of plastid $r b c L, t r n L$ intron, trnL-F intergenic spacer, rnatK, and $n d h F$, and mitochondrial atp 1 DNA sequences. Clade A includes Amana and Tulipa, clade B includes Cardiocrinum, Fritillaria and Lilium, clade C includes, Clintonia and Medeola, clade D includes, clade A, clade B, clade C and Gagea and clade E includes Streptopus, Prosartes and Scoliopus. We analyzed Fritillaria, Gagea and Tulipa in our research. In both trees Fritillaria, Gagea and Tulipa is sister and show strong relationship.

In recent years, phylogenetic relationships among members of genus Orchis and allied genera Aceras, Barlia, Neotinea, Ophyrs, Anacamptis, Dactylorhiza, Cephalanthera, Himantoglossum and Serapias were inferred from nucleotide sequence variation in the internal transcribed spacer (ITS) regions of nrDNA, cpDNA and RFLP's. The results of these studies showed that, some molecular data give close concordance with floral morphology but some others conflict. Previous authors separated Orchis some sections based on karyology, molecular data, morphology and enzymatic characters (Vermeulen's, 1972; Cauwet-Marc and Balayer, 1984; Rossi et al., 1994). Phylogenetic relations of Orchis and some related genera also studied by some researchers (Cozzolino et al., 1997; Acto et al., 1998). Molecular analysis based on ITS region data set and a chloroplast DNA restriction fragment length polymorphism carried out Cozzolino et al. (1998) and Aceto et al. (1998) showed that Orchis is parahyletic. This consequence depends on the fact that Orchis also contains Acreas and Dactylorhiza. In this relevant study except Acreas, Orchis and allied genera Dactlylorhiza, Serapias, Cephalanthera, Anacamptis and Himantoglossum phylogenetic relationships were investigated. The phylogenetic hypothesis represented here show contrasts with the previous knowledge based on morphology of Vermeulen (1972). Phylogenetic analysis depends on ITS show congruent with the results of trnL-F. One of the relevant differences between the two analyses is in the position of Serapias and Cephalanthera which are external group to Orchis in phylogenetic tree based on ITS sequences and sister group each other in phylogenetic tree constructed by trnL-F data. The other difference is the position of the Anacamptis, which is nested in our ingroup in trnL-F analysis whereas spread in Orchis species considering the ITS sequences. According to the results of Aceto et al. (1998) consensus tree for ITS shows Himantoglossum at the base of the tree in a sister group relationship of the rest of the ingroup. On the contrary of this results, our both ITS and trnL-F analysis results shows that Dactlylorhiza and Himantoglossum are in close relationship with Orchis, Allium belongs to Amarylidaceae family of the monocot Asparagales order as Orchidaceae family. Phylogenetic results based on nuclear and chloroplast derived sequences are compatible with the expected close relationship between Orchis and Allium.

Ixioideae, the largest subfamily of Iridaceae and diverse from other members by having specialized pollen grains with tectateperforate and scabrate sculpturing (Goldblatt et al., 1991). Crocoideae is the synonyms of the Ixioideae and represented by three genera in the flora of Turkey: Crocus, Romulea and Gladiolus (Güner et al., 2000). Based on their connate tepals, sessile flowers, operculate pollen with porous sculpturing exine, closed leaf sheath, and having corm they are count in monophyletic (RashedMohassel, 2006). Crocus and Gladiolus are dissimilar to the other members of the subfamily by the terms of corm structure (Erol et al., 2008). According to our results of ITS and trnL-F data sequences Crocus and Gladiolus show very close relationship. Also, Iris belongs to Iridaceae subfamily of Iridoideae and tribe Irideae (Goldblatt, 2000). Gynandriris is a genus in Irideae tribe and Moraea Mill. Moreae and Iris constitute the major genera of Iridaea. Moraea have Iris-like flowers (Allen, 1975), however, Iris shows vegetative diversity whereas Moreae is characterized by vegetative uniformity and floral divergence (Goldbatt, 2000). Gynandriris sisyinchium (L.) Parl., Morea austris is nested in Iris in phylogenetic tree constructed by trnL-F data. Irideceae and allied family Asian Ixioliriaceae not indicated by external morphology. According to Goldbatt (2000) these two families is differentiated very long time ago and their relationship have been obscured at the morphological level and Iridaceae appear phylogenetically isolated (Goldbatt, 2000). Chase et al. (1995) studied molecular phylogeny by plastid gene $r b c \mathrm{~L}$ and indicated that Iridaceae and Ixioliriaceae specify strong closer relationship among other members of Asparagales (Chase et al., 1995). Clearly considering the ITS and trnL-F derived trees Iridaceae and Ixioliriaceae are phylogenetically separated.

Muscari and Scilla are belonged to the Asparagaceae, subfamily of Scilloideae. Both sequences data indicate close relationship of Muscari and Scilla. Previous data also revealed Muscari closely related to Scilla (Pfosser and Speta, 1999). 
The Ranunculus and Anemone are members of Ranunculaceae. Cladistic molecular analysis of Ranunculaceae was done by some researchers as Johansson and Jansen (1993), Johansson (1995), and Hoot (1995) and they closely allied Ranunculus to Anemone L. We found that Ranunculus and
Anemone show close relationship and relevant data support the preceding researches.

In conclusion, molecular systematics of all species belonging to the genera should take into account in order to clearly identify the genera of the studied geophytic taxa and to reveal the intraspecific and interspecific relationships clearly.

Table 1. Accession number from the NCBI database

\begin{tabular}{|c|c|c|}
\hline Specimens & Internal transcribed spacer (ITS) & $t r n L-F$ \\
\hline Fritillaria imperialis & AY616725.1 & \\
\hline Fritillaria chitralensis & AY616716.1 & \\
\hline Fritillaria minuta & AY616733.1 & \\
\hline Fritillaria crassifolia & AY616717.1 & \\
\hline Fritillaria thunbergii & & KF851029.1 \\
\hline Tulipa armena var. armena & Q776500.1 & \\
\hline Tulipa julia & HF952964.1 & \\
\hline Tulipa borszczowii & HF952959.1 & \\
\hline Tulipa agenensis & JQ280384.1 & \\
\hline Iris minutoaurea & KT119547.1 & \\
\hline Iris odaesanensis & KT595384.1 & \\
\hline Iris lactea & DQ277639.1 & \\
\hline Iris koreana & KT634245.1 & \\
\hline Iris caucasica subsp. turcica & & KY319464.1 \\
\hline Iris histrio & & JQ413996.1 \\
\hline Crocus biflorus subsp. adamii & HE663958.1 & \\
\hline Crocus almehensis & HE801162.1 & \\
\hline Crocus roopiae & LN864717.1 & \\
\hline Crocus neglectus & & КT357298.1 \\
\hline Ornithogalum refractum & HQ615075.1 & \\
\hline Gagea fragifera & EU912046.1 & AM283102.1 \\
\hline Gagea villosa var. hermonis & & KU232888.1 \\
\hline Ixiolirion tataricum & & KF261069.1 \\
\hline Ranunculus linearilobus & MW737445.1 & \\
\hline Ranunculus leptorrhynchus & MW737444.1 & \\
\hline Ranunculus oxyspermus & MT271834.1 & \\
\hline Ranunculus kochii & AY680193.1 & \\
\hline Anemone edwardsiana & FJ639880.1 & \\
\hline Corydalis pumila & MN662999.1 & \\
\hline Corydalis paczoskii & & HE603350.1 \\
\hline Bunium elegans & KF974538.1 & \\
\hline Bunium allioides & $\mathrm{J} \times 312805.1$ & \\
\hline Allium pallens & KP221824.1 & \\
\hline Allium paniculatum & AJ411949.1 & \\
\hline Allium longipapillatum & MK776898.1 & \\
\hline Allium chrysantherum & MG944302.1 & \\
\hline Allium cardiostemon & FM177277.1 & \\
\hline Allium rothii & FM177400.1 & \\
\hline Allium oleraceum & & FJ628602.1 \\
\hline Allium sativum & & EU626261.1 \\
\hline Allium latifolium & & MT130438.1 \\
\hline Serapias orientalis & KY512512.1 & \\
\hline Serapias nurrica & & EF690287.1 \\
\hline Anacamptis papilionacea & KY512514.1 & \\
\hline Anacamptis coriophora & MF944259.1 & KU931746.1 \\
\hline Anacamptis palustris & KU931742.1 & \\
\hline Orchis purpurea & MT179742.1 & \\
\hline Orchis adenocheila & KU931695.1 & \\
\hline Cephalanthera humilis & & JN706694.1 \\
\hline Dactylorhiza umbrosa & & KU931765.1 \\
\hline Ornithogalum refractum & & HQ645873.1 \\
\hline Gladiolus illyricus & & KM887320.1 \\
\hline Ixiolirion tataricum & & AJ290314.1 \\
\hline Eminium spiculatum & & AM933357.1 \\
\hline Geranium tuberosum & & KY606615.1 \\
\hline
\end{tabular}

Table 2. Numeric information of ITS and trnL-F

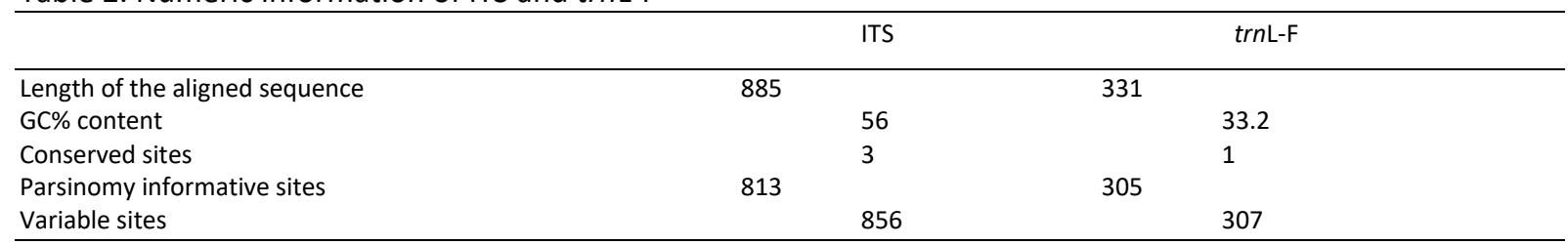




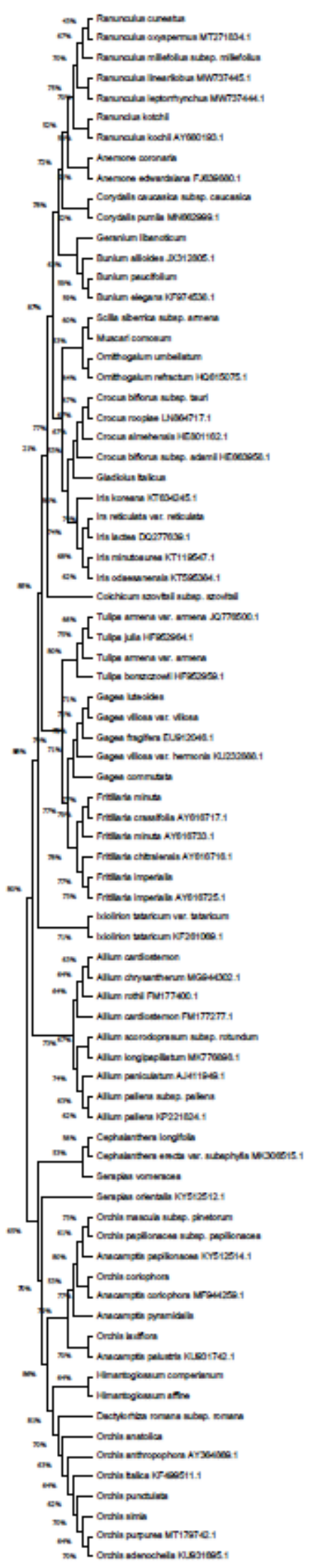

Figure 1. Maximum Likelihood tree based upon the Tamura-Nei model of nrDNA ITS region with 1000 bootstrap replicates. 


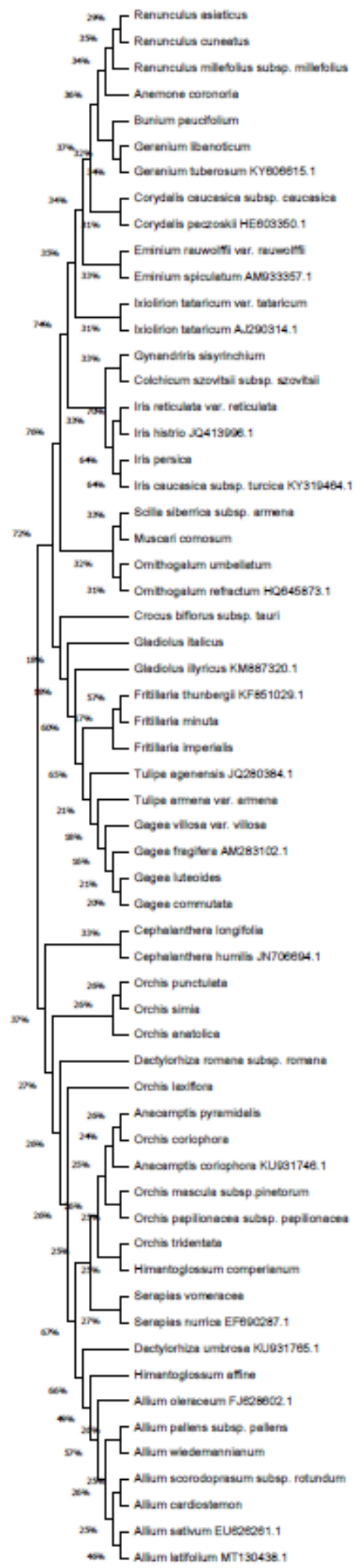

Figure 2. Maximum Likelihood cpDNA tree based on the data obtained from the sequences of the trnL-F 
Acknowledgements: This research was supported by Bingol Universtiy BUBAP unit (BAP-FEF. 2021. 011).

Conflict of Interest Statement: The authors of the article declare that there is no conflict of interest between them.

Contrubution Rate Statement Summary of Researchers: The authors declare that they have contributed equally to the article.

\section{References}

Aceto, S., Caputo, P., Cozzolino, S., Gaudio, L. and Moretti, A. 1999. Phylogeny and Evolution of Orchis and Allied Genera Based on ITS DNA Variation: Morphological Gaps and Molecular Continuity. Molecular Phylogenetics and Evolution, 13: 67-76.

Akdeniz, N.S. and Zencirkıran, M. 2016. Bursa Geophytes and Their Usage Possibilities in Landscape Design. Journal of Agricultural Faculty of Uludag University, 30, 692-702.

Anonymous. 2020. T.C. Tarım ve Orman Bakanlığı web site, https://arastirma. tarimorman.gov.tr/beykozbbgam/Belgeler/ Teknik\%20Bilgi/Geofitler.pdf

Cauwet-Marc, A.M. and Balayer, M. 1984. Les genres Orchis L., Dactylorhiza Necker ex Newski, Neotinea Reichb. et Traunsterinera Reichb.: Caryologie et proposition de phyloge'nie et d'e'volution. Bot. Helvetica, 94: 391-406.

Chase, M.W., Duval, M.R., Hillis, H.G., Conran, J.G., Cox, A.V., Eguiarte, L.E., Hartwell, J., Fay, M.F., Caddick, L.R., Cameron, K.M. and Hoot, S. 1995. Molecular phylogenetics of Lilianae. Pp. 109-137 in P. J. Rudall, P. J. Cribb, D. F. Cutler, and C. J. Humphries, eds. Monocotyledons: systematics and evolution. The Royal Botanical Gardens, Kew, U.K.

Çı̆̆, A. and Başdoğan, G. 2015. In vitro propagation techniques for some geophyte ornamental plants with high economic value. International Journal of Secondary Metabolite, 2(1), 27-49.

Cozzolino, S., Aceto, S., Caputo, P., Nazzaro, R. and Gaudio, L. 1998. Phylogenetic relationships in Orchis and some related genera: An approach using chloroplast DNA. Nord. J. Bot., 18: 79-87.

Cuéllar-Martínez, M. and Sosa, V. 2016. Diversity patterns of monocotiledonous geophytes in Mexico. Botanical Sciences, 94: 699.
Dafni, A., Cohen, D. and Noy-Mier, I. 1981. Lifecycle variation in geophytes. Annals of the Missouri Botanical Garden, 68:652-660. DOI: $10.2307 / 2398893$

Davis, P.H. 1965-1985. Flora of Turkey and East Aegean Islands. Vol:1-9 University Press, Edinburg.Press. Edinburgh: U.K; 1965.

Doussi, M.A. and Thanos, C.A. 2002. Ecophysiology of seed germination in Mediterranean geophytes. 1. Muscari spp. Seed Science Research, 12:193-201.

Douzery, E.J.P., Pridgeon, A.M., Kores, P., Linder, H.P., Kurzweil, H. and Chase, M.W. 1999. Molecular phylogenetics of Diseae (Orchidaceae): A contribution from nuclear ribosomal ITS sequences. Am. J. Bot., 86: 887-899.

Dyer, R.A. 1975. The Genera of Southern African Flowering Plants. ISBN 0-621-02854-1.

Ebersberger, A., Telleria-Diaz, A., Natura, G., Eitner, A., Halbhuber, K.J. and Schaible, H.G. 2007. Prostaglandin D2 modulates nociceptive signalling and prostaglandin E2 effects in dorsal root ganglion neurons and spinal cord. Soc Neurosci Abstr, 33:184-9.

Erol, O., Kucuker, O. and Uzen, E. 2008. Corm tunic morphology of Turkish Crocoideae (Iridaceae) and their systematic significance. Nordic Journal of Botany 26: 66-73.

Evans, M., Aubriot, X., Hearn, D., Lanciaux, M., Lavergne, S., Cruaud, C., Lowry, P.P. and Haevermans., T. 2014. Insights on the evolution of plant succulence from a remarkable radiation in Madagascar (Euphorbia). Systematic Biology, 63: 697711.

Fay, M.F., Chase, M.W., Ronsted, N., Devey, D.S., Pillon, Y., Pires, C., Peterson, G., Seberg, O. and Davis, J.I. 2006. Phylogenetics of Liliales. Phylogenetics of Liliales: Summarized Evidence from Combined Analyses of Five Plastid and One Mitochondrial Loci. Aliso, 22: 559-565.

Fernández-Mazuecos, M., Mellers, G., Vigalondo, B., Sáez, L., Vargas, P. and Glover, B.J. 2017. Resolving recent plant radiations: power and robustness of genotyping-bysequencing. Systematic Biology, doi:10.1093/sysbio/ syx062.

Goldblatt, P., Manning, J.C., Bari, A. 1991. Sulcus and Operculum Structure In The Pollen Grains of Iridaceae Subfamily Ixioideae. Ann. Missouri Bot. Gard., 78: 950-961. 
Goldblatt, P. 2000. Phylogeny and Classification of the Iridaceae and the relationships of Iris. Annali Botanica., 58: 13-28.

Güner, H., Ekim, T., Koyuncu, M., Erik, S., Yıldız, B. and Vural, M. 1991. Türkiye'nin Ekonomik Önem Taşıyan Geofitleri Üzerine Taksonomik ve Ekolojik Araştırmalar, Ankara.

Güner, H. 2006. Inventory of Growing Geophytes in the Botanical Gardens in Istanbul Turkey. Master Thesis. Istanbul University, Institute of Science and Technology, Istanbul.

Güner, A., Özhatay, N., Ekim, T., Başer, K.H.C. (editors) 2000. Flora of Turkey and the East Aegean Islands (Suppl. 2), Vol. 11. Edinburgh, UK: Edinburgh University Press.

Güner, A. (editors) 2018. Resimli Türkiye Florası (Illustrated Flora of Turkey) Vol:2. NAMAŞ Yayınları, ISSN: 978-605-67172-3-9.

Hoffmann, A.J., Liberona, F. and Hoffmann, A.E. 1998. Distribution and ecology of geophytes in Chile. Conservation threats to geophytes in Mediterraneantype regions. In: Rundel, P.W., Montenegro, G. And Jaksic, F.M. [eds.], Landscape disturbance and biodiversity in Mediterranean-type ecosystems, 231-253. Springer Nature, New York, New York, USA.

Hoot, S.B. 1995. Phylogeny of the Ranunculaceae based on preliminary atpB, rbcL and

$18 \mathrm{~S}$ nuclear ribosomal DNA sequence data. PI. Syst. Evol., Suppl., 9: 241-251.

Jansen, R.K. 1993. Chloroplast DNA variation and phylogeny of the Ranunculaceae. Pl. Syst. Evol., 187: 29-49.

Johansson, J. T. 1995. A revised chloroplast DNA phylogeny of the Ranunculaceae. Pl. Syst. Evol., Suppl., 9: 253-261.

Kamenetsky, R. 2013. Biodiversity of geophytes, phytogeography, morphology and survival strategies. In: Kamenetsky R. and Okubo H. Eds. Ornamental geophytes: from basic science to sustainable production, pp. 5771. CRC. Press, Boca Raton.

Kamenetsky, R. and Hiroshi, O. 2013. Ornamental Geophytes from Basic Science to Sustainable Production, CRC Press, U.S., 1519.

Koniak, G., Noy-Meir, I. and Perevolotsky, A. 2009. Estimating multiple benefits from vegetation in Mediter-ranean ecosystems. Biodiversity and Conservation, 18:34833501. DOI: 10.1007/S10531-009-9656-9.

Mallo, D. and Posada, D. 2016. Multilocus inference of species trees and DNA barcoding. Philos. Trans. R. Soc. London B, 371, 20150335.
Meerow, A.W. 2013. Taxonomy and phylogeny. In: Kamenestky R, Okubo H, Eds. Ornamental geophytes: from basic science to sustainable production. Boca Raton: CRC Press, 17-55.

Oberlander, K.C., Emshwiller, E., Bellstedt, D.U. and Dreyer, L.L. 2009. A model of bulb evolution in the eudicot genus Oxalis (Oxalidaceae). Molecular Phylogenetics and Evolution, 51: 54-63.

Özhatay, N., Byfeld, A. ve Atay, S. 2003. Türkiye'nin Önemli Bitki Alanları, WWF Türkiye (Doğal Hayatı Koruma Vakfı), İstanbul.

Parsons, R.F., and Hopper, S.D. 2003. Monocotyledonous geophytes: Comparison of south-western Australia with other areas of mediterranean climate. Australian Journal of Botany, 51: 129-133.

Parsons, R.F. 2000. Monocots geophytes: comparison of California with Victoria, Australia. American Journal of Botany, 48:39-43. DOI: 10.1971/ BT98056.

Pate, J.S. and Dixon K.W. 1982. Tuberous, cormous and bulbous plants. Biology of an adaptive strategy in Western Australia. International Scholarly Book Services Inc., Beaverton, Oregon, USA.

Patterson, T.B. and Givnish, T.J. 2002. Phylogeny, concerted convergence, and phylogenetic niche conservatism in the core Liliales: insights from $\mathrm{rbc} L$ and $n d h \mathrm{~F}$ sequence data. Evolution, 56: 233-252.

Perret, M., Chautems, A., Spichiger, R., Kite, G. and Savolainen, V. 2003. Systematics and evolution of tribe Sinningieae (Gesneriaceae): $\quad$ Evidence from phylogenetic analyses of six plastid DNA regions and nuclear ncpGS. American Journal of Botany, 90: 445-460.

Pfosser, M. and Speta, F. 1999. Phylogenetics of Hyacinthaceae based on plastid DNA sequences. Annals of the Missouri Botanical Garden, 86, 852-875.

Procheş, S., Cowling, R.M. and du Preez, D.R. 2005. Patterns of geophyte and storage organ size in the win-ter-rainfall region of southern Africa. Diversity and Distributions, 11:101-109. DOI: 10.111/j.13669516.2005.00132.x

Procheş, S., Cowling, R.M., Goldblatt, P., Manning, J.C. and Snijman, D.A. 2006. An overview of the Cape geo-phytes. Biological Journal of the Linnean Society, 87:27-43. DOI: 10.1111/j.1095-8312.2006.00557.x 
Rashed-Mohassel, M.H. 2006. Saffron Botany. 1st edition. eBook ISBN9780429083242.

Raunkiaer, C. 1934. The life forms of plants and statistical plant geography. Oxford University Press, London, UK.

Rossi, W., Corrias, B., Arduino, P., Cianchi, R. and Bullini, L. 1994. Multilocus electrophoresis and European orchid systematics: The genus Orchis and related genera. Proc. 14th World Orchid Conf. Glasgow. HMSO: 78-83.

Rundel, P. W. 1996. Monocotyledonous geophytes in the California flora. Madrono 43: 355368.

Seyidoğlu, N., Zencirkıran, M., Ayaşlıgil, Y. 2009. Position and application areas of geophytes within landscape design. African Journal of Agricultural Research, I: 4 (12), pp. 1351-1357.

Sonboli, A. and Oberprieler, C. 2010. Phylogenetic relationship and taxonomic position of Xylanthemum tianschanicum(Krasch.) Muradyan (Compositae, Anthemideae) as inferred from nrDNA ITS data. Biochem. Syst. Ecol., 38: 702-707.

Sosa, V. and Loera, I. 2017. Influence of current climate, historical climate stability and topography on species richness and endemism in Mesoamerican geophyte plants. PeerJ 5: e3932.

Sosa, V., Cameron, K.M., Angulo, D.F. and Hernández-Hernández, T. 2016. Life form evolution in epidendroid orchids: Ecological consequences of the shift from epiphytism to terrestrial habit in Hexalectris. Taxon, 65: 235-248.

Taberlet, P., Gielly, L., Pautou, G. and Bovet, J. 1991. Universal primers for amplification of three non-coding regions of chloroplast DNA. Plant Mol. Biol., 17: 1105-1109.

Tamura, K., Stecher, G., Kumar, S. 2021. MEGA11:

Molecular Evolutionary Genetics Analysis Version 11. Molecular Biology and Evolution., 38: 3022-3027.

Thompson, J.D. 1994. CLUSTAL W: improving the sensitivity of progressive multiple sequence alignment through sequence weighting, position-specific gap penalties and weight matrix choice. Nucleic Acids Res., 22: 4673-4680.

Tyler, C. and Borchert, M. 2003. Reproduction and growth of the chaparral geophyte, Zigadenus fremontii (Lili-aceae), in relation to fire. Plant Ecology, 165:11-20. DOI: 10.1023/A:1021460025277.

Verboom, G.A., Stock, W.D. and Linder, H.P. 2002. Determinants of postfire flowering in the geophytic grass Eh-rharta capensis. Functional Ecology, 16:705-713. http://www.jstor.org/stable/826600

Vermeulen, P. 1972. U" bersicht zur Systematik und Taxonomie derGattung Orchis s. str. Jahresber. Naturwiss. Ver. Wuppertal, 25: 22-36.

Veselý, P., Bureš, P., Šmarda, P. and Pavlíček, T. 2012. Genome size and DNA base composition of geophytes: the mirror of phenology and ecology? Annals of Botany, 109:65-75. DOI: 10.1093/aob/mcr267.

Wilson, C.A. 2006. Patterns in evolution in characters that define Iris subgenera and sections. Aliso, 22: 425.433.

Zencirkıran, M. 2002. Geophytes. Uludağ Rotary Derneği Yayınları No:1, ISBN: 975-93004-00 . 